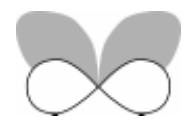

\title{
Reconciling fossils and molecules: Cenozoic divergence of cichlid fishes and the biogeography of Madagascar
}

\author{
M. Vences ${ }^{1 *}$, J. Freyhof ${ }^{2}$, R. Sonnenberg ${ }^{3}$, J. Kosuch ${ }^{4}$ and M. Veith ${ }^{4}{ }^{1}$ Muséum National \\ d'Histoire Naturelle, Laboratoire des Reptiles et Amphibiens, 25 rue Cuvier, 75005 Paris, \\ France, ${ }^{2}$ Institute of Freshwater Ecology and Inland Fisheries, Department of Biology \\ and Ecology of Fishes, Müggelseedamm 310, Berlin 12561, Germany, ${ }^{3}$ Zoologisches \\ Forschungsinstitut und Museum Alexander Koenig, Adenauerallee 160, 53113 Bonn, \\ Germany, and ${ }^{4}$ Zoologisches Institut der Universität Mainz, Abteilung Ökologie, Saarstrasse \\ 21, Mainz 55099, Germany.
}

\begin{abstract}
Aim The biogeographical origins of the extant vertebrates endemic to Madagascar are largely unsolved, but have often been related to vicariance in the context of fragmentation of the supercontinent Gondwana in the Mesozoic. Such hypotheses are especially appealing in the case of cichlid fishes, which show phylogenetic relationships reflecting the temporal successions of the breakup of Gondwana. We used molecular clock data to test this assumption.
\end{abstract}

Location Fragments of the 16S rRNA gene and of the nuclear Tmo-4C4 locus, partly obtained from Genbank from South American, African, Malagasy and Indian cichlids were analysed.

Methods Based on monophyletic cichlid radiations in African lakes, we calibrated a molecular clock. The obtained rates were used to estimate the age of divergence of the major cichlid clades.

Results The results agreed better with a Cenozoic than with a Mesozoic divergence, and were in accordance with the fossil record. Sequence divergences of the $16 \mathrm{~S}$ and $12 \mathrm{~S}$ rRNA genes of most lineages of Malagasy terrestrial and freshwater vertebrates from their non-Malagasy sister groups were below saturation and many were relatively similar to those of cichlids.

Main conclusions A Cenozoic dispersal from continental landmasses may explain the origin of most extant Malagasy vertebrate groups better than a Jurassic/Cretaceous vicariance.

\section{Keywords}

Teleostei, Perciformes, Cichlidae, Madagascar, phylogeny, dispersal vs. vicariance.

\section{INTRODUCTION}

The biogeographical origins of the extant terrestrial and freshwater vertebrate fauna of Madagascar have been characterized as one of the largest unsolved questions of

*Correspondence: Zoologisches Forschungsinstitut und Museum Alexander Koenig, Adenauerallee 160, 53113 Bonn, Germany.

E-mail: m.vences@t-online.de natural history (Krause et al., 1997a). Geological data indicate an ancient mid-Mesozoic separation of Madagascar from the African mainland (Rabinowitz et al., 1983; Storey, 1995). Madagascar harbours several groups of mammals (lemurs, tenrecs, herpestid carnivores, nesomyine rodents), reptiles, anuran amphibians, and fishes, with only two larger groups of freshwater fish (cichlids and cyprinodontiforms). Although Malagasy terrestrial and freshwater vertebrates are 
often basal within their respective higher taxa (e.g. Parenti, 1981; Stiassny \& de Pinna, 1994), they all belong to relatively modern groups. 'Living fossils' such as osteoglossomorph and polypteriform fishes, archaeobatrachian frogs, sphenodontid lizards, or monotreme mammals are lacking in Madagascar, indicating a 'biotic change in deep time' (Krause et al., 1997a).

Nevertheless, an old Mesozoic origin has been assumed for several extant Malagasy vertebrate lineages. Fishes in the family Cichlidae are a group which display a typical Gondwanan distribution. A few basal forms are found in Madagascar and India, while diverse lineages occur in Africa and South America. According to molecular and morphological data (Stiassny, 1991; Streelman \& Karl, 1997; Streelman et al., 1998; Farias et al., 1999, 2000), the African and South American lineages together form a monophylum which is the sister group of the Malagasy and Indian taxa. This agrees with the succession of events leading to the fragmentation of Gondwana: separation of the Madagascar-India continent from Africa at 165-121 Myr в , separation of Africa and South America at 101-86 Mуг в , and separation of Madagascar and India at 88-63 Myr вр (Rabinowitz et al., 1983; Pitman et al., 1993; Storey et al., 1995; Storey, 1995). Considering this concordance, it is appealing to hypothesize that the separation of the main extant cichlid lineages may have been linked to the breakup of Gondwana, which implies a radiation of cichlids in the Early Cretaceous (Stiassny, 1991; Farias et al., 1999). However, it has been pointed out by Lundberg (1993) that such an early origin and diversification is in conflict with palaeontological data. The first cichlid fossils are known from the Eocene (Murray, 2000, 2001). Cichlids belong to the Acanthomorpha, an extremely large clade with 280 nominal families which is not known before the Upper Cretaceous (Patterson, 1993).

Researchers in recent decades have been highly interested in the evolution of cichlids. The species flocks in the East African lakes Tanganyika, Malawi and Victoria provide spectacular examples of rapid evolutionary radiation (Meyer, 1993). Cichlids in each of the three lakes belong to one or few monophyletic intralacustrine lineages, respectively, each of which led to similar ecological adaptations (Greenwood, 1984; Meyer et al., 1990; Sturmbauer \& Meyer, 1993; Sturmbauer et al., 1994; Nishida, 1997). The monophyletic cichlid radiation in the small volcanic crater lake Barombi Mbo has served as a model for sympatric speciation processes (Schliewen et al., 1994). As suggested by geological data, these ecological and morphological diversifications occurred over short time frames: Lake Tanganyika, 12-4 Myr в ; Lake Malawi, 2-1 Myr вр; Barombi Mbo, $1 \mathrm{Myr}$ в or less; Lake Victoria, 10.012 Myr вр (McCune, 1997).

In the present study, we used the most conservative geological datings of lake origins, and the divergence among their endemic cichlid radiations, to calibrate a molecular clock. We applied these divergence rates to the splits among major cichlid lineages to test for their assumed Mesozoic divergence.

\section{MATERIALS AND METHODS}

Data came from (1) fragments of the mitochondrial $16 \mathrm{~S}$ rRNA gene homologous to bp 4038-4504 of the Xenopus laevis mitochondrial genome (GenBank accession number M10217; Roe et al., 1985), and (2) partial sequences of a single-copy nuclear gene (Tmo-4C4 locus; Streelman \& Karl, 1997). Many of the sequences included were publically available from GenBank. This was true for all Tmo-4C4 sequences (twenty-four species; accession numbers U70327-U70331, U70335-U70343, U70345, U70347U70351, U70356-U70358, U70361; Streelman \& Karl, 1997, 1998) and to sixty-four sequences of the 16S rRNA gene (accession numbers AF045842-AF045865, AF048996AF049019, AF112577-AF112596; Farias et al., 1999). We complemented these data by sequencing homologous $16 \mathrm{~S}$ rRNA fragments of twenty-four species from the lakes Tanganyika, Malawi, Victoria, and Barombi Mbo (accession numbers AF215453-AF215476; vouchers of all but eight species deposited in the Zoologisches Forschungsinstitut und Museum A. Koenig: ZFMK 26449-26460 and 27686-27689); Malawi (Mbuna): Aulonocara baenschi Meyer \& Riehl, 1985, Maylandia estherae (Konings, 1995). Malawi (non-Mbuna): Aristochromis christyi Trewavas, 1935, Cyrtocara moori Boulenger, 1902, Dimidiochromis strigatus (Regan, 1922), Rhamphochromis cf. woodi Regan, 1922. Tanganyika (Ectodini): Callochromis pleurospilus (Boulenger, 1906), Ectodus descampsi (Boulenger, 1898), Gnathochromis permaxillaris (David, 1936), Grammatotria lemairei Boulenger, 1899, Xenotilapia ornatipinnis Boulenger, 1901. Tanganyika (Lamprologini): Altolamprologus compressiceps (Boulenger, 1898), Lamprologus moori Boulenger, 1898, Lepidiolamprologus elongatus (Boulenger, 1898), Telmatochromis sp. Victoria: Haplochromis ishmaeli Boulenger, 1906 (Gulf of Mwaza), Haplochromis (Yssichromis) pyrrhocephalus Witte \& WitteMaas, 1987, Haplochromis (Paralabidochromis) sp., Haplochromis piceatus Greenwood \& Gee, 1969, Neochromis rufocaudalis Seehausen \& Bouton, 1998, Platytaeniodus degeni Boulenger, 1906. Barombi Mbo: Stomatepia pindu Trewavas, 1972, Stomatepia mariae (Holly, 1930), Sarotherodon cf. steinbachi (Trewavas, 1962).

In the 16S rRNA fragment, we based molecular clock calibrations on the sequences obtained by us, and intercontinental divergence calculations on the combined data set. We calibrated the Tmo-4C4 clock and calculated the corresponding intercontinental divergences based entirely on GenBank sequences; for calibrations the following species were used: Malawi (Mbuna): Labidochromis caeruleus Fryer, 1956, Pseudotropheus sp. (tropheops complex); Tanganyika (Ectodini): Enantiopus melonogenys (Boulenger, 1898), Cunningtonia longiventralis Boulenger, 1906; Tanganyika (Lamprologini): Julidochromis regani Poll, 1942, A. compressiceps (Boulenger, 1898), Neolamprologus brichardi (Poll, 1974).

Sequence divergence was also calculated in the $16 \mathrm{~S}$ rRNA gene for a number of mammal species pairs, several of which have been used in the past to calibrate molecular clocks 
applied to cichlids (Meyer, 1993) and other fishes (e.g. Bargelloni et al., 1994). Sequences came entirely from GenBank while all divergences were re-calculated by us. The species pairs and assumed ages of divergence were Cervus unicolor Kerr, 1792 - Muntiacus revesii (Ogilby, 1839) (7 Myr вP), Gazella thomsoni Günther, 1884 Madoqua kirki (Günther, 1880) (16.5 Myr вр), Bos taurus Linnaeus, 1758 - Capra hircus Linnaeus, 1758 (20 Myr вр), Capra hircus - Ovis aries Linnaeus, 1758 (5 Myr вр), Bos taurus - Ovis aries (20 Myr BP), Bos taurus - Antilocapra americana (Ord, 1815) (20 Myr ВР), Bos taurus - Cervus unicolor (25 Myr ВР), Bos taurus - Muntiacus revesii (25 Myr вр), Equus caballus Linnaeus, 1758-Equus asinus Linnaeus, 1758 (4 Myr вP) (GenBank accessions M35875, M35877, M86501, M86495, J01394, M55541, AF010406, M55540, X79547, X97337; Irwin et al., 1991; Allard et al., 1992; Rassmann, 1997; Pesole et al., 1999).

All eighty-eight cichlid 16S rRNA sequences were aligned using the Clustal option of the program SEQUENCE NAVIGATOR (Applied Biosystems); alignments were adjusted manually (total $16 \mathrm{~S}$ alignment length including gaps: 500 bp). We used the program MODELTEST (Posada \& Crandall, 1998) to estimate the substitution model that best fits the data. The estimated settings were then used to calculate maximum likelihood (ML) phylogenies and pairwise maximum likelihood distances in PAUP*, version 4.0b8 (Swofford, 2001). Additionally, we calculated neighbourjoining and maximum parsimony trees.

We tested for rate constancy of a molecular clock using a likelihood-ratio test (Felsenstein, 1988) as implemented in TREE-PUZZLE (Strimmer \& von Haeseler, 1996). Relative rate tests (Takezaki et al., 1995) were conducted using the program PHYLTEST (Kumar, 1996). Relying on combined phylogenies of mitochondrial and nuclear genes (Farias et al., 2000), sequences of the Malagasy and Indian cichlids were used as outgroups for relative rate comparisons between South American and African taxa, and sequences of representatives of Abudefduf Forsskål, 1775 and Cymatogaster Gibbons, 1854 as outgroups for comparisons between Indian and Malagasy taxa, and between IndianMalagasy and African taxa. Ages of divergence were estimated (1) using percentages of transversion divergence between taxa, assuming their linear accumulation, and (2) via pairwise maximum likelihood distances. These distances were included in a regression analysis to calculate $95 \%$ prediction confidence intervals.

\section{RESULTS}

\section{Estimation of substitution model}

The hierarchical likelihood ratio tests implemented in MODELTEST selected a Tamura-Nei substitution model with a proportion of invariable sites of 0.4093 , a $\gamma$ shape distribution parameter of 0.6115 , empirical base frequencies $\quad$ (freq $\mathrm{A}=0.3897 ; \quad$ freqC $=0.2737 ;$ freq $=0.1091$; freq $\mathrm{T}=0.2276)$ and substitution rates $(\mathrm{A}-\mathrm{G}=6.5303$; $\mathrm{C}-\mathrm{T}=7.7596$; all other rates $=1$ ) as best fitting the complete
16S alignment (including sequences obtained from GenBank as well as sequences obtained by us). This model was used to calculate maximum likelihood distances in PAUP*.

\section{Phylogenetic analysis}

Alignment of the $16 \mathrm{~S}$ fragments sequenced by us to those available from GenBank did not yield any problems. A phylogenetic analyses of the complete set (sixty-four taxa from GenBank and twenty-four taxa sequenced by us), using maximum likelihood, maximum parsimony and neighbourjoining methods (results not shown), produced tree topologies largely compatible with the published cladograms of Farias et al. (1999). Three main lineages were distinguished, corresponding to the (1) African, (2) South American and (3) Indian and Malagasy taxa. The Indian and Malagasy species were the sister group of all other cichlids. The Malagasy Paretroplus polyactis Bleeker, 1878 was the sister group of the Indian Etroplus maculatus (Bloch, 1795) (bootstrap support in the neighbour-joining analysis: 95\%). The South American clade was a monophylum $(72 \%)$ and formed the sister group of the African clade. In all taxa sampled by us, the corresponding $16 \mathrm{~S}$ fragments clustered within the African lineage.

\section{Rate constancy}

Clock like evolution of both the 16S and the Tmo-4C4 fragment was rejected by the likelihood ratio test at significance levels of $P<0.01$.

The relative rate comparison (values given for analyses based on transitions and transversions; and based on transversions only) between $16 \mathrm{~S}$ rRNA sequences of the South American lineage $(\mathrm{La}=0.099 ; 0.036)$ and the African lineage $(\mathrm{Lb}=0.050 ; 0.014)$ corroborated the results of Farias et al. (1999) regarding an accelerated substitution rate in the Neotropical taxa. Rate constancy was rejected at the $0.05 \quad$ level $\quad(\mathrm{La}-\mathrm{Lb}=0.0451 \pm 0.0096, \quad Z=4.712$; $0.0223 \pm 0.0045, Z=4.929$ ). Rate constancy between the African lineage of cichlids ( $\mathrm{La}=0.049 ; 0.016)$ and the Indian and Malagasy taxa $(\mathrm{Lb}=0.051 ; 0.017)$ was not rejected $(Z=0.293 ; 0.169)$. The same was true when comparing the Indian/Malagasy clade separately with only the (1) Tanganyika, (2) Malawi, (3) Victoria and (4) Barombi Mbo taxa $(Z=0.636,1.304,0.604,0.788$; $Z=0.841,0.823,0.506,0.716)$.

In the relative rate comparisons between $\mathrm{Tmo}-4 \mathrm{C} 4$ sequences of the South American lineage $(\mathrm{La}=0.047$; $0.011)$ and the African lineage $(\mathrm{Lb}=0.067 ; 0.020)$ rate constancy was not rejected $(Z=1.766 ; 1.347)$. Rate constancy was rejected at the 0.05 level in comparison of the Neotropical species to the Malawi and Tanganyika cichlids considering transitions and transversions $(Z=2.169)$; but not considering transversions alone $(Z=1.500)$. Rate constancy between the African cichlids $(\mathrm{La}=0.075 ; 0.024)$ and the Indian and Malagasy taxa $(\mathrm{Lb}=0.036 ; 0.007)$ was rejected $(Z=3.535 ; 2.556)$. 


\section{Molecular clock calibrations}

The $16 \mathrm{~S}$ calibrations (Table 1) resulted in pairwise transversion rates of $0.042-0.103 \%$ per $\mathrm{Myr}$ BP and maximum likelihood distance rates of $0.00147-0.00496 \mathrm{Myr}$ BP (on average $0.077 \%$ transversions per Myr BP, and a maximum likelihood distance rate of $0.00290 \mathrm{Myr}$ в $)$. The transversion substitution rates calculated using twelve mammal species pairs were $0.05-0.22 \%$ per Myr в P (mean $0.09 \%$ per Myr BP), indicating that the rates calculated for cichlids were not particularly fast. The estimated substitution rates in the Tmo-4C4 sequences were slightly lower as compared to the $16 \mathrm{~S}$ rRNA gene fragment (Table 2).

\section{Divergence time estimates}

Values of 16S and Tmo-4C4 sequence differentiation found among major geographical cichlid lineages are shown in Table 3. Based on our calibrations, the split between the African and the Malagasy/Indian lineage was estimated to have occurred at 56 or $41 \mathrm{Myr}$ BP (based on mean total and transversion rates of Tmo-4C4, respectively), $41 \mathrm{Myr}$ в (mean 16S transversion rate), or $35 \mathrm{Myr}$ BP with $95 \%$ prediction confidence intervals of $84-15 \mathrm{Myr}$ BP (16S maximum likelihood distances). The split estimate between the Malagasy Paretroplus polyactis and the Indian Etroplus maculatus was 25 or 5 Myr вр (Tmo-4C4), 29 Myr вр (16S transversion rate), or $27 \mathrm{Myr}$ B $\mathrm{P}$ with prediction confidence intervals of 43-5 Myr BP (16S maximum likelihood

Table I Calibrations of the molecular clock in a fragment of the 16S rRNA gene using endemic cichlids of the Tanganyika, Malawi and Barombi Mbo lakes (no differences were observed among Victoria lake cichlids). Data are given as mean, followed by range of all pairwise comparisons (in parentheses). The oldest available geological age estimate of the lakes was chosen. The Tanganyika calibration is based on two endemic radiations which have been demonstrated to be monophyletic, the Ectodini and the Lamprologini (Sturmbauer \& Meyer, 1993; Sturmbauer et al., 1994; Nishida, 1997). The Lamprologini are less suited for a calibration as they contain riverine species, and the lacustrine taxa may be paraphyletic; they were included following a conservative approach, as the divergence levels between the lamprologine species were lower than between the included ectodines. Malawi cichlids can be classified in three lineages, the Mbuna, the non-Mbuna (e.g. Moran et al., 1994), and the basal genus Rhamphochromis. The Mbuna and non-Mbuna are monophyletic intralacustrine radiations; most probably all Malawi cichlids are a monophyletic group (Meyer, 1993). The mean mammal values are based on fossil evidence for species pairs (see Materials and Methods) which in the past were used to calibrate molecular clocks in cichlids and other animal groups

\begin{tabular}{|c|c|c|c|c|c|c|c|}
\hline \multirow[b]{2}{*}{ Comparison } & \multirow[b]{2}{*}{$\begin{array}{l}\text { All substitutions } \\
(\%)\end{array}$} & \multirow[b]{2}{*}{$\begin{array}{l}\text { Transversions } \\
\text { only }(\%)\end{array}$} & \multirow{2}{*}{$\begin{array}{l}\text { Transition/ } \\
\text { transversion } \\
\text { ratio }\end{array}$} & \multirow[b]{2}{*}{$\begin{array}{l}\text { Geological } \\
\text { age (max.) }\end{array}$} & \multicolumn{3}{|l|}{ Substitution rate } \\
\hline & & & & & $\begin{array}{l}\text { All substitutions } \\
(\%)\end{array}$ & $\begin{array}{l}\text { Transversion only } \\
\text { (\% per Myr вP) }\end{array}$ & $\begin{array}{l}\text { ML distances } \\
(\% \text { per Myr вP) }\end{array}$ \\
\hline $\begin{array}{l}\text { Tanganyika } \\
\text { (Ectodini) }\end{array}$ & $\begin{array}{l}4.23 \\
(3.4-5.2)\end{array}$ & $\begin{array}{l}1.23 \\
(0.40-1.80)\end{array}$ & $3.2(1.6-7.5)$ & 12 & 0.353 & 0.103 & 0.00421 \\
\hline $\begin{array}{l}\text { Tanganyika } \\
\text { (Lamprologini) }\end{array}$ & $\begin{array}{l}2.8 \\
(2.0-3.4)\end{array}$ & $\begin{array}{l}0.5 \\
(0-0.80)\end{array}$ & $4.3(2.3-7.5)$ & 12 & 0.233 & 0.042 & 0.00252 \\
\hline Malawi (Mbuna) & 0.6 & 0 & - & 2 & 0.300 & - & 0.00297 \\
\hline $\begin{array}{l}\text { Malawi } \\
\text { (non-Mbuna) }\end{array}$ & $\begin{array}{l}0.27 \\
(0-0.40)\end{array}$ & 0 & - & 2 & 0.133 & - & 0.00131 \\
\hline Barombi Mbo & 0.3 & 0 & - & 1 & 0.300 & - & 0.00194 \\
\hline Average & & & & & 0.292 & 0.077 & 0.00290 \\
\hline $\begin{array}{l}\text { Average } \\
\text { for mammals }\end{array}$ & & & & & 0.515 & 0.087 & - \\
\hline
\end{tabular}

Table 2 Calibrations of the molecular clock using nuclear sequences at the Tmo-4C4 locus in endemic cichlids of the Tanganyika and Malawi lakes. See Table 1 for further explanations

\begin{tabular}{|c|c|c|c|c|c|c|}
\hline \multirow[b]{2}{*}{ Comparison } & \multirow[b]{2}{*}{$\begin{array}{l}\text { All substitutions } \\
(\%)\end{array}$} & \multirow[b]{2}{*}{$\begin{array}{l}\text { Transversions } \\
\text { only }\end{array}$} & \multirow[b]{2}{*}{$\begin{array}{l}\text { Transition/ } \\
\text { transversion ratio }\end{array}$} & \multirow[b]{2}{*}{$\begin{array}{l}\text { Geological } \\
\text { age }(\max )\end{array}$} & \multicolumn{2}{|l|}{ Substitution rate } \\
\hline & & & & & $\begin{array}{l}\text { All substitutions } \\
\text { (\% per Myr вр) }\end{array}$ & $\begin{array}{l}\text { Transversion only } \\
\text { (\% per Myr вр) }\end{array}$ \\
\hline Tanganyika (Ectodini) & 3.5 & 1.4 & 2.6 & 12 & 0.292 & 0.117 \\
\hline Tanganyika (Lamprologini) & $1.2(0.4-1.6)$ & $0.4(0.2-0.6)$ & $2.9(2.0-4.0)$ & 12 & 0.100 & 0.033 \\
\hline Malawi (Mbuna) & 0.4 & 0 & - & 2 & 0.200 & - \\
\hline Average & & & & & 0.197 & 0.075 \\
\hline
\end{tabular}


Table 3 Differentiation (pairwise sequence divergences in percent and ML distances) between major cichlid clades in the considered gene fragments. Data are given as mean, followed by range (in parentheses). The India-Madagascar comparison is based on Etroplus and Paretroplus; for the 16S rRNA gene, the Africa-South America comparison is based on Retroculus (most basal South American genus) and all African taxa, for the nuclear gene it is based on Astronotus and Crenicichla (South America) and all African taxa

\begin{tabular}{lllll}
\hline Comparison & $\begin{array}{l}\text { All substitutions } \\
(\%)\end{array}$ & $\begin{array}{l}\text { Transversions only } \\
(\%)\end{array}$ & $\begin{array}{l}\text { Transition/trans- } \\
\text { version ratio }\end{array}$ & ML distances \\
\hline 16S: Africa - Madagascar/India & $9.54(7-16.2)$ & $3.14(1.6-7.8)$ & $2.3(1.0-5.1)$ & $0.13166(0.102-0.165)$ \\
16S: India (Etroplus) - Madagascar (Paretroplus) & 7.0 & 2.2 & 3.2 & 0.10165 \\
16S: Africa - South America (Retroculus) & $11.4(8.4-16)$ & $4.16(2.4-7)$ & $1.9(1.2-3.2)$ & $0.17926(0.152-0.258)$ \\
Tmo-4C4: Africa - Madagascar/India & $11(9-13.3)$ & $3.1(2.5-4.3)$ & $3.5(2.6-4.4)$ & - \\
Tmo-4C4: India (Etroplus) - Madagascar & 4.9 & 0.4 & 12.5 & - \\
(Paretroplus) & $11.4(8.0-14.5)$ & $3.1(2.2-4.1)$ & $3.7(2.8-4.2)$ & - \\
Tmo-4C4: Africa - South America & & & & \\
\hline
\end{tabular}

distances). The split estimate between the African and South American cichlids was 58 or $41 \mathrm{Myr}$ в (Tmo-4C4), $54 \mathrm{Myr}$ Ве (16S transversion rate), or $47 \mathrm{Myr}$ BP with prediction confidence intervals of $78-24 \mathrm{Myr}$ BP (16S maximum likelihood distances).

\section{DISCUSSION}

\section{Molecular clock restrictions}

The molecular estimates of the age of divergence between major cichlid lineages were considerably younger than the geological datings of the respective continental drift events
(Fig. 1). These results must be viewed with caution, considering the severe restrictions inherent in molecular clock datings (see Hillis et al., 1996). The potential problem of uncertain calibrations based on single events was addressed by including several independent calibrations and two separate gene fragments, and by calculating prediction confidence intervals. It also is unlikely that saturation phenomena played a major role, as (1) the $16 \mathrm{~S}$ divergences were below the $15-20 \%$ pairwise differentiation which marks the saturation plateau (Ortí \& Meyer, 1997; Farias et al., 1999), (2) calibrations were based on transversions which accumulate in a linear fashion even after transitions

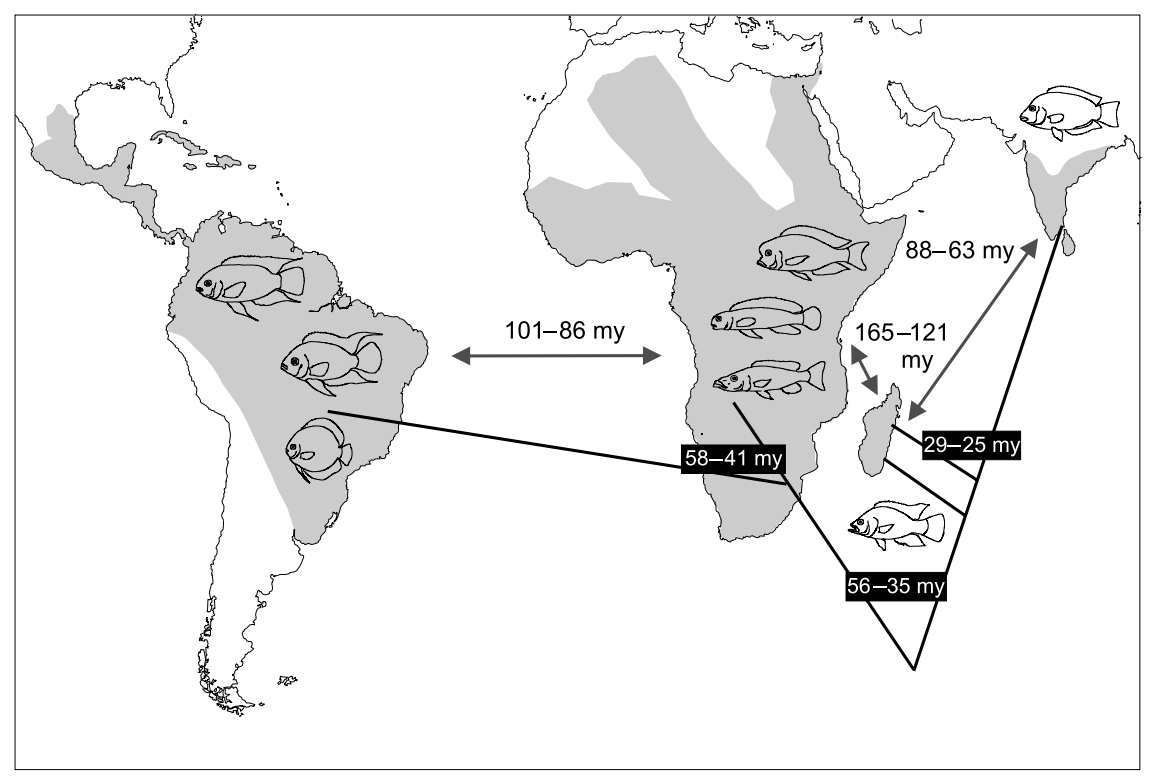

Figure I World-wide distribution (Stiassny, 1991) and phylogeny (Farias et al., 1999, 2000) of cichlids. Branch lengths of the cladogram have been adjusted to fit the geographical distance between continents and are not indicative of degree of sequence divergence. The two branches pointing to Madagascar indicate the paraphyly of Malagasy cichlids (Paretroplus being the sister group of the Indian Etroplus and not of other Malagasy taxa). Molecular age estimates of the splits between geographical cichlid lineages are given in black bars on the basis of these splits (range of the mean estimates obtained in separate calculations as explained in the text). The geological age of separation of the continents and continent fragments is given next to the grey arrows which mark these separations. The low age estimate of 5 my for the split between Indian and Malagasy taxa based on transversion differentiation at the Tmo-4C4 locus was considered as outlier and not included in the figure. 
are saturated, or on maximum likelihood distances which consider specific substitution rates, and (3) the Tmo-4C4 sequences did not show signs of saturation in higher-order comparisons between families of labroid fishes (Streelman \& Karl, 1997), and thus were certainly not saturated within the Cichlidae.

Furthermore, our calibrations were conservative as (1) the oldest available geological dating for each of the lakes was used, despite the fact that most workers assumed younger ages of the cichlid species flocks, (2) we did not use the deepest splits in each lineage but the mean of all splits for calibration, (3) only lineages with well assessed monophyly (except the Lamprologini; see caption to Table 1) were used, which may not represent the earliest radiations in the respective lakes and (4) the Lamprologini were included although the rates obtained from this group were lower than those obtained from ectodines.

In contrast, the partial lack of rate constancy was an important problem applying to the present estimates in cichlid fishes. The likelihood ratio test rejected a clock-like evolution of the studied gene fragments in the taxa included. In several cases, rate constancy between the taxa used for calibration and other geographical clusters was rejected. Occasionally this was caused by a faster rate in the taxa used for calibration. If such a calibration is applied, it will result in a underestimation of the actual divergence time. This may be the case in the Tmo-4C4 locus, in which faster rates (about doubled branch lengths) in the African species were detected. But even assuming such a $100 \%$ rate acceleration in the groups used for calibration, the mean age estimates would lay outside the ranges of the respective geological events.

However, it should be emphasized that in the $16 \mathrm{~S}$ analyses, the African species used for calibration had a slower rate than the Indian, Malagasy and especially the South American taxa (as obvious from the comparison of the branch lengths from the relative rate tests which are roughly equivalent to substitution rates). Such a situation could lead to an overestimation of divergence times; nevertheless, the estimated ages were still much younger than expected under a vicariance model. The total $16 \mathrm{~S}$ differentiation between Etroplus (India) and Paretroplus (Madagascar) was 7\%, while the deepest split in the ectodine Tanganyika radiation was $5.2 \%$. No significant rate differences between both groups were detected. The youngest geological dating available for the former divergence is $63 \mathrm{Myr} \mathrm{BP}$, while the oldest dating of the latter divergence was $12 \mathrm{Myr}$ вP. Assuming Madagascar-India vicariance would in this case imply a fourfold increase in the rate of sequence differentiation in the ectodines, which certainly would not have passed unperceived by the rate test.

\section{Cichlid evolution: a dispersal scenario}

Considering the conservative nature of our estimates, it can at least be stated that the observed levels of genetic divergence appear to agree better with a Cenozoic than a Mesozoic divergence. This implies that cichlid evolution was not linked to mesozoic continental fragmentation and claims for an explanation of the implied dispersal events. Recent geological findings support the existence of small emergent islands between Madagascar and Africa from the mid-Eocene to the early Miocene (McCall, 1997). Even if these islands did not form continuous landbridges (Krause et al., 1999), they may have been used as stepping stones in times of lower sea levels. We assume that during the Early Cenozoic the ancestral cichlids were widespread in Africa and dispersed to Madagascar and India. Posterior radiations of modern cichlid fishes in Africa displaced these basal lineages, causing their extinction except for those in the Malagasy and Indian regions. The highly endangered status of most Malagasy cichlid species caused by the introduction of Tilapia and mouth-brooding Oreochromis species from Africa (Stiassny \& Raminosoa, 1994) shows how representatives of the more modern cichlid lineages can displace the more basal cichlids in a very short time span (probably $<200$ years).

The dispersal hypothesis further implies that Neotropical cichlids (which are the sister group of the African clade) reached South America long after its assumed separation from Africa at 106-84 Myr BP. Two other vertebrate groups are thought to have reached South America from Africa in the Cenozoic, platyrrhine primates and caviomorph rodents (Carroll, 1988). Age of divergence of platyrrhines from Old World monkeys has been estimated as $35 \mathrm{Myr}$ BP (Schneider et al., 1993). The earliest rodent record from South America is 35-31 Myr B et al., 1991). These 'old island hoppers' may have reached South America by colonizing the Caribbean plate directly from Africa or via North America, and then dispersing to South America along island chains for which geological evidence exists (Marshall \& Sempere, 1993). Several Neotropical cichlids are known to be tolerant of brackish water. It is therefore sound to assume that their ancestors were able to use the same dispersal routes as caviomorph and platyrrhine ancestors, even without invoking a closed direct land connection between Africa and South America.

\section{Origin of non-flying vertebrates of Madagascar}

Beside cichlids, a Gondwanan origin has also been assumed for other Malagasy vertebrates, among them aplocheiloid fishes (Murphy \& Collier, 1997) and hyperoliid frogs (Duellman \& Trueb, 1986; Richards \& Moore, 1996). Also in these groups an Early Cretaceous radiation is in conflict with the fossil record (Lundberg, 1993; Patterson, 1993; Sanchiz, 1998; see also Feller \& Hedges, 1998). We determined levels of divergence of most Malagasy terrestrial and freshwater vertebrates to their non-Malagasy sister groups, using about 300 sequences obtained by us (GenBank accession numbers AF215132-215509) and 100 further sequences from GenBank (detailed results will be published in forthcoming papers). The overall mean differentiation of the mitochondrial $16 \mathrm{~S}$ and $12 \mathrm{~S}$ rRNA genes was mostly below their saturation level. This was true for groups showing affinities to India (aplocheiloids, 13\%), Africa (hyperoliids, 13\%; chameleons, $12 \%$; scincid lizards, 
7-11\%; colubrid snakes, 9-12\%; tortoises, 7\%; lemurs, $18 \%$; herpestid carnivores, $8 \%$; tenrecs, $16 \%$; nesomyine rodents, $11 \%$ ) as well as South America (boas, 8\%; iguanas, $14 \%$; podocnemine turtles, $11 \%$ ). Although reliable calibrations are not yet available, most of these values are not too different from those of cichlids (Table 3) and appear to match better the assumption of Cenozoic than Early Cretaceous divergences. The highest values correspond to mammal groups (tenrecs and lemurs) which almost certainly did not yet radiate in the mid-Cretaceous (Carroll, 1988).

\section{CONCLUSIONS}

Although the available evidence favours dispersal scenarios, a more or less important vicariance component in the extant Malagasy fauna can certainly not be excluded at the current state. We are convinced, however, that in cichlids dispersal played at least a major role. This situation corresponds in some respects to the intensively discussed problem of Caribbean biogeography. For this region, vicariance scenarios have been advocated based on phylogenies of different organism groups (Page \& Lydeard, 1994; Crother \& Guyer, 1996). These hypotheses are, however, heavily contradicted by molecular clocks which favour a Cenozoic re-colonization of the islands after extinction of the original faunas, probably by the consequences of an extraterrestrial bolide impact at the K-T boundary (Hedges et al., 1992, 1994; Hedges, 1996). Although it is appealing to advocate vicariance and disregard scenarios of (concordant) dispersal if phylogenies match the assumed plate tectonical history, the Caribbean example shows that all available evidence (including amounts of molecular divergences and fossil evidence) should be considered.

Unfortunately, Tertiary fossils from Madagascar are virtually lacking (Krause et al., 1997a, 1999). However, the rich fauna from the latest Cretaceous of Madagascar did not yield any cichlid or aplocheiloid fishes but draws the picture of a primitive assemblage with little phylogenetic relatedness to the recent Malagasy fauna (Krause et al., $1997 \mathrm{a}$, b). Thus, explaining the origin of most extant Malagasy vertebrates by ancient vicariance implies conflicts with palaeontological findings and molecular divergence levels.

Transmarine dispersal is a common pattern shaping island faunas in the Indian Ocean region and accounts for the origin of most reptile taxa of the Mascarene islands (Arnold, 2000). To invoke a limited faunal exchange between Madagascar and other continental landmasses, especially Africa, in the early Cenozoic eliminates the contradictions between data sets and explains satisfyingly the origin of most Malagasy vertebrate groups.

\section{ACKNOWLEDGMENT}

We are grateful to Frans Witte (Leiden) and Frank Schäfer (Rodgau) who supplied several of the studied specimens, and to Bernhard Misof (Bonn) for fruitful discussions. The constructive remarks of two anonymous referees helped improving the manuscript. The work was in part supported by a grant of the Deutsche Forschungsgemeinschaft DFG (BO 682/5-1).

\section{REFERENCES}

Allard, M.W., Miyamoto, M.M., Jarecki, L., Kraus, F. \& Tennant, M.R. (1992) DNA systematics and evolution of the artiodactyl family Bovidae. Proceedings of the National Academy of Sciences of the USA, 89, 3972-3976.

Arnold, E.N. (2000) Using fossils and phylogenies to understand evolution of reptile communities on islands. Isolated vertebrate communities in the tropics (ed. G. Rheinwald), pp. 309-323. Bonner zool. Monogr. 46. Museum A. Koenig, Bonn.

Bargelloni, L., Ritchie, P.A., Patarnello, T., Battaglia, B., Lambert, D.M. \& Meyer, A. (1994) Molecular evolution at subzero temperatures: mitochondrial and nuclear phylogenies of fishes from Antarctica (suborder Notothenioidei), and the evolution of antifreeze glycopeptides. Molecular Biology and Evolution, 11, 854-863.

Carroll, R.L. (1988) Vertebrate paleontology and evolution. Freeman, New York.

Crother, B.I. \& Guyer, C. (1996) Caribbean historical biogeography: was the dispersal-vicariance debate eliminated by an extraterrestrial bolide? Herpetologica, 52, 440-465.

Duellman, W.E. \& Trueb, L. (1986) Biology of amphibians. Mc Graw-Hill, New York.

Farias, I.P., Orti, G. \& Meyer, A. (2000) Total evidence: molecules, morphology, and the phylogenetics of cichlid fishes. Journal of Experimental Zoology, 288, 76-92.

Farias, I.P., Orti, G., Sampaio, I., Schneider, H. \& Meyer, A. (1999) Mitochondrial DNA phylogeny of the family Cichlidae: monophyly and fast molecular evolution of the neotropical assemblage. Journal of Molecular Evolution, 48, 703-711.

Feller, A.E. \& Hedges, S.B. (1998) Molecular evidence for the early history of living amphibians. Molecular Phylogenetics and Evolution, 9, 509-516.

Felsenstein, J. (1988) Phylogenies from molecular sequences: inference and reliability. Annual Review of Genetics, 22, 521-565.

Flynn, J.J., Norell, M.A., Swisher, C.C. III \& Wyss, A.R. (1991) Pre-Deseadan, post-Mustersan mammals from Central Chile. An update. Journal of Vertebrate Paleontology, (Abstracts) 11 (Suppl.), 29A.

Greenwood, P.H. (1984) African cichlids and evolutionary theories. Evolution of cichlid species flocks (eds A.A. Echelle and I. Kornfield), pp. 141-154. University of Maine Press, Orono.

Hedges, S.B. (1996) Vicariance and dispersal in Caribbean biogeography. Herpetologica, 52, 466-473.

Hedges, S.B., Hass, C.A. \& Maxson, L.R. (1992) Caribbean biogeography: molecular evidence for dispersal in West Indian terrestrial vertebrates. Proceedings of the National Academy of Sciences of the USA, 89, 1909-1913.

Hedges, S.B., Hass, C.A. \& Maxson, L.R. (1994) Towards a biogeography of the Caribbean. Cladistics, 10, 43-55. 
Hillis, D.M., Mable, B.K. \& Moritz, C. (1996) Applications of molecular systematics. Molecular systematics, 2 nd edn (eds D.M. Hillis, C. Moritz and B.K. Mable), pp. 515-543. Sinauer Associates, Sunderland, MA.

Irwin, D.M., Kocher, T.D. \& Wilson, A.C. (1991) Evolution of the cytochrome $b$ gene of mammals. Journal of Molecular Evolution, 32, 128-144.

Krause, D.W., Hartman, J.H. \& Wells, N.A. (1997a) Late Cretaceous vertebrates from Madagascar. Implications for biotic changes in deep time. Natural change and buman impact in Madagascar (eds S.M. Goodman and B.D. Patterson), pp. 3-43. Smithsonian Institution Press, Washington.

Krause, D.W., Prasad, G.V.R., Koenigswald, W.V., Sahni, A. \& Grine, F.E. (1997b) Cosmopolitanism among Gondwanan Late Cretaceous mammals. Nature, 390, 504-507.

Krause, D.W., Rogers, R.R., Forster, C.A., Hartman, J.H., Buckley, G.A. \& Sampson, S.D. (1999) The Late Cretaceous vertebrate fauna of Madagascar: implications for Gondwanan paleobiogeography. GSA Today (a Publication of the Geological Society of America), 9, 1-7.

Kumar, S. (1996) PHYLTEST: phylogeny bypothesis testing software. The Pennsylvania State University, Pennsylvania.

Lundberg, J.G. (1993) African-South American freshwater fish clades and continental drift: problems with a paradigm. Biology relationships between Africa and South America (ed. P. Goldblatt), pp. 156-199. Yale University Press, New Haven.

Marshall, L.G. \& Sempere, T. (1993) Evolution of the Neotropical Cenozoic land mammal fauna in its geochronological, stratigraphic, and tectonic context. Biology relationships between Africa and South America (ed. P. Goldblatt), pp. 329-392. Yale University Press, New Haven.

McCall, R.A. (1997) Implications of recent geological investigations of the Mozambique Channel for the mammalian colonization of Madagascar. Proceedings of the Royal Society of London (B), 264, 663-665.

McCune, A.R. (1997) How fast is speciation? Molecular, geological and phylogenetic evidence from adaptive radiations of fishes. Molecular evolution and adaptive radiation (eds T.J. Givnish and K.J. Sytsma), pp. 585-610. Cambridge University Press, Cambridge.

Meyer, A. (1993) Phylogenetic relationships and evolutionary processes in East African cichlids. Trends in Ecology and Evolution, 8, 279-284.

Meyer, A., Kocher, T.D., Basaslbwaki, P. \& Wilson, A.C. (1990) Monophyletic origin of Lake Victoria cichlid fishes suggested by mitochondrial DNA sequences. Nature, 347, 550-553.

Moran, P., Kornfield, I. \& Reinthal, P.N. (1994) Molecular systematics and radiation of the haplochromine cichlids (Teleostei: Perciformes) of Lake Malawi. Copeia, 1994, 274-288.

Murphy, W.J. \& Collier, G.E. (1997) A molecular phylogeny for aplocheiloid fishes (Atherinomorpha, Cypridontiformes): the role of vicariance and the origins of annualism. Molecular Biology and Evolution, 14, 790-799.

Murray, A.M. (2000) Eocene cichlid fishes from Tanzania, East Africa. Journal of Vertebrate Paleontology, 20, 651-664.
Murray, A.M. (2001) The oldest fossil cichlids (Teleostei: Perciformes): indication of a 45 million-year-old species flock. Proceedings of the Royal Society B, 268, 679-684.

Nishida, M. (1997) Phylogenetic relationships and evolution of Tanganyikan cichlids: a molecular perspective. Fish Communities in Lake Tanganyika (eds H. Kawanabe, M. Hori and M. Nagoshi), pp. 3-23. Kyoto University Press, Kyoto.

Ortí, G. \& Meyer, A. (1997) The radiation of characiform fishes and the limits of resolution of mitochondrial ribosomal DNA sequences. Systematic Biology, 46, 75-100.

Page, R.D.M. \& Lydeard, C. (1994) Towards a cladistic biogeography of the Caribbean. Cladistics, 10, 21-41.

Parenti, L.R. (1981) A phylogenetic and biogeographic analysis of Cyprinodontiform fishes (Teleostei: Atherinomorpha). Bulletin of American Museum of Natural History, 168, 336-557.

Patterson, C. (1993) An overview of the early fossil records of acanthomorphs. Bulletin of Marine Science, 52, 29-59.

Pesole, G., Gissi, C., De Chirico, A. \& Saccone, C. (1999) Nucleotide substitution rate of mammalian mitochondrial genomes. Journal of Molecular Evolution, 48, 427-434.

Pitman, W.C. III, Cande, S., LaBrecque, J. \& Pindell, J. (1993) Fragmentation of Gondwana: the separation of Africa from South America. Biology relationships between Africa and South America (ed. P. Goldblatt), pp. 15-34. Yale University Press, New Haven.

Posada, D. \& Crandall, K.A. (1998) Modeltest: testing the model of DNA substitution. Bioinformatics, 14, 817-818.

Rabinowitz, P.D., Coffin, M.F. \& Falvey, D. (1983) The separation of Madagascar and Africa. Science, 220, 67-69.

Rassmann, K. (1997) Evolutionary age of the Galapagos iguanas predates the age of the present Galapagos Islands. Molecular Phylogenetics and Evolution, 7, 158-172.

Richards, C.M. \& Moore, W.S. (1996) A phylogeny for the African treefrog family Hyperoliidae based on mitochondrial rDNA. Molecular Phylogenetics and Evolution, 5, 522-532.

Roe, B.A., Din-Pow, M., Wilson, R.K. \& Wong, J.F. (1985) The complete nucleotide sequence of the Xenopus leavis mitochondrial genome. Journal of Biological Chemistry, 260, 9759-9774.

Sanchiz, B. (1998) Encyclopedia of paleoherpetology. Part. 4. Salientia. Pfeil, München.

Schliewen, U.K., Tautz, D. \& Pääbo, S. (1994) Sympatric speciation suggested by monophyly of crater lake cichlids. Nature, 368, 629-632.

Schneider, H., Schneider, M.P.C., Sampaio, I., Harada, M.L., Stanhope, M., Czelusniak, J. \& Goodman, M. (1993) Molecular phylogeny of the New World monkeys (Platyrrhini, Primates). Molecular Phylogenetics and Evolution, 2, 225-242.

Stiassny, M.L.J. (1991) Phylogenetic intrarelationships of the family Cichlidae: an overview. Cichlid fishes. Behaviour, ecology and evolution (ed. M.H.A. Keenleyside), pp. 1-35. Chapman \& Hall, London.

Stiassny, M.L.J. \& de Pinna, M.C.C. (1994) Basal taxa and the role of cladistic patterns in the evaluation of conservation priorities: a view from freshwater. Systematics and conservation evaluation (eds P.L. Forey, C.J. Humphries and 
R.I. Vane-Wright), pp. 235-249. Systematics Association special Volume no. 50. Clarendon Press, Oxford.

Stiassny, M.L.J. \& Raminosoa, N. (1994) The fishes of the inland waters of Madagascar. Annales du musée royale d'Afrique centrale, zoology, 275, 133-149.

Storey, B.C. (1995) The role of mantle plumes in continental breakup: case histories from Gondwanaland. Nature, 377, 301-308.

Storey, M., Mahoney, J.J., Saunders, A.D., Duncan, R.A., Kelley, S.P. \& Coffin, M.F. (1995) Timing of hot spot-related volcanism and the breakup of Madagascar and India. Science, $167,852-855$.

Streelman, J.T. \& Karl, A. (1997) Reconstructing labroid evolution with single-copy nuclear DNA. Proceedings of the Royal Society of London (B), 264, 1011-1020.

Streelman, J.T., Zardoya, R., Meyer, A. \& Karl, S.A. (1998) Multi-locus phylogeny of cichlid fishes: evolutionary comparison of microsatellite and single-copy nuclear loci. Molecular Biology and Evolution, 15, 798-808.
Strimmer, K. \& von Haeseler, A. (1996) Quartet puzzling: a quartett maximum likelihood method for reconstructing tree topologies. Molecular Biology and Evolution, 13, 964-969.

Sturmbauer, C. \& Meyer, A. (1993) Mitochondrial phylogeny of the endemic mouthbrooding lineages of cichlid fishes from Lake Tanganyika in Eastern Africa. Molecular Biology and Evolution, 10, 751-768.

Sturmbauer, C., Verheyen, E. \& Meyer, A. (1994) Mitochondrial phylogeny of the Lamprologini, the major substrate spawning lineage of cichlid fishes from Lake Tanganyika in Eastern Africa. Molecular Biology and Evolution, 11, 691-703.

Swofford, D.L. (2001) PAUP*. Phylogenetic analysis using parsimony ("and other methods), v. 4b8. Sinauer Associates, Sunderland, MA.

Takezaki, N., Rzhetsky, A. \& Nei, M. (1995) Phylogenetic test of the molecular clock and linearized trees. Molecular Biology and Evolution, 12, 823-833.

\section{BIOSKETCHES}

Dr Miguel Vences is a postdoctoral scientist, working from 2000-2001 at the Muséum national d'Histoire naturelle in Paris. He has intensively studied systematics, biogeography and molecular phylogeny of amphibians and other vertebrates of Madagascar for more than 10 years.

Dr Jörg Freyhof works as a researcher in the Institute of Freshwater Ecology and Inland Fisheries in Berlin. His interests focus on evolutionary biology and ecology of freshwater fishes.

Rainer Sonnenberg is working on his $\mathrm{PhD}$ at the Zoologisches Forschungsinstitut und Museum A. Koenig, Bonn, on the phylogeography of African aplocheiloid fishes.

Joachim Kosuch is working on his $\mathrm{PhD}$ at the Mainz University. His main interests focus on molecular phylogeny, phylogeography and systematics of amphibians.

Dr Michael Veith works as an assistant professor at the Mainz University. His research interests cover the phylogeography of amphibians and the genetic structure of animal populations in fragmented landscapes. 